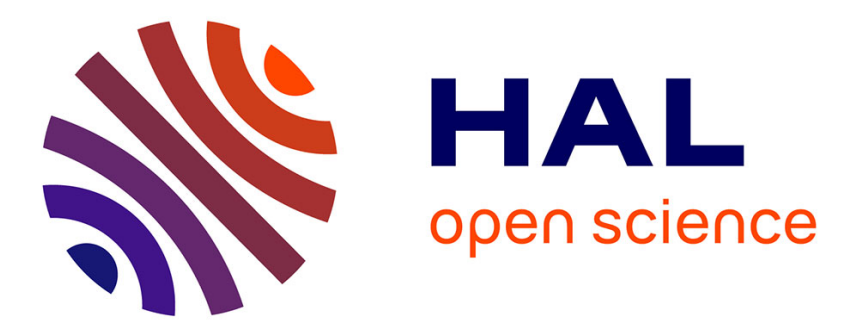

\title{
Field-scale estimation of the volume percentage of rock fragments in stony soils by electrical resistivity
}

Marion Tetegan, Catherine Pasquier, Bernard B. Nicoullaud, Hocine

Bourennane, Arlène Besson, Caroline Desbourdes-Coutadeur, Alain Bouthier, Dominique D. King, Isabelle I. Cousin

\section{To cite this version:}

Marion Tetegan, Catherine Pasquier, Bernard B. Nicoullaud, Hocine Bourennane, Arlène Besson, et al.. Field-scale estimation of the volume percentage of rock fragments in stony soils by electrical resistivity. CATENA, 2012, 92, pp.67-74. 10.1016/j.catena.2011.09.005 . hal-02652709

\section{HAL Id: hal-02652709 \\ https: / hal.inrae.fr/hal-02652709}

Submitted on 29 May 2020

HAL is a multi-disciplinary open access archive for the deposit and dissemination of scientific research documents, whether they are published or not. The documents may come from teaching and research institutions in France or abroad, or from public or private research centers.
L'archive ouverte pluridisciplinaire HAL, est destinée au dépôt et à la diffusion de documents scientifiques de niveau recherche, publiés ou non, émanant des établissements d'enseignement et de recherche français ou étrangers, des laboratoires publics ou privés. 
Version définitive du manuscrit publié dans / Final version of the manuscript published in :

Catena, 92, 67-74

\title{
Estimating the volume percentage of rock fragments of a stony soil by electrical resistivity at the field scale
}

\author{
M. Tetegan ${ }^{\text {a, b }}$, C. Pasquier ${ }^{\text {a }}$, B. Nicoullaud ${ }^{\text {a }}$, H. Bourennane ${ }^{\text {a }}$, A. Besson ${ }^{\text {a, c }}$, C. Desbourdes- \\ Coutadeur $^{\text {d }}$, A. Bouthier ${ }^{\text {b }}$, D King ${ }^{\text {a }}$, I. Cousin ${ }^{\text {a }}$ \\ ${ }^{a}$ Institut National de la Recherche Agronomique, UR 0272 Science du Sol, 2163 Avenue de la Pomme de Pin, \\ CS 40001 Ardon 45075 Orléans Cedex 2 - France \\ ${ }^{\mathrm{b}}$ ARVALIS - Institut du Végétal, Domaine expérimental du Magneraud 17700 Saint Pierre d'Amilly - France \\ ${ }^{c}$ Institut National de la Recherche Agronomique, UMR LISAH, 2 place Pierre Viala, 34060 Montpellier cedex 1 \\ - France \\ d ARVALIS - Institut du Végétal, 45 voie Romaine, 41240 Ouzouer le Marché - France
}

\begin{abstract}
Analysing the properties and functional characteristics of heterogeneous soils containing several phases requires a correct estimation of the volume proportion of each phase. In the case of stony soils, the volume percentage of the content of rock fragments remains difficult to estimate in situ. This paper presents a method that uses field spatial electrical resistivity measurements to determine the volume proportion of rock fragments. Based on the hypothesis that the electrical resistivity signal noise increases as the proportion of rock fragments increases, a model was developed that uses the standard deviation of the apparent electrical resistivity measurements over a small area as an indicator of rock fragment contents. The model was tested on three study areas of several hectares containing soil units with varying quantities of rock fragments. The estimation of the rock fragment content was accurate, and the error estimation of about $6 \%$ was the same order of magnitude as the Bussian model (1983). The developed model strongly depends on the water content in the soil and the rock type and must be calibrated in each context. Nevertheless, estimations of the rock fragment content in stony soils can be performed efficiently in the surface horizon as well as all along the soil profile.
\end{abstract}


Version définitive du manuscrit publié dans / Final version of the manuscript published in :

Catena, 92, 67-74

\section{Introduction}

Currently, it remains difficult to provide estimates of the hydraulic properties of stony soils at the regional scale. To avoid bias, the hydraulic properties of stony soils must account for the presence of both rock fragments and fine earth, i.e., the characteristic individual hydraulic properties, and their volume content (Cousin et al., 2003; Tetegan et al., 2011; Ugolini et al., 1998). The estimation of the volume content of rock fragments is challenging although several methods have been used for a long time. For instance, estimates of rock fragment content can be measured from the soil surface reflectance by remote sensing; this method distinguishes among soil types and soil surface conditions, such as soil micro topography and vegetation cover (Girard and Girard, 2003). Other studies have demonstrated that a relationship exists between the percentage of rock fragments and the brightness index (Bhattacharya and Chandrakar, 1999; Mathieu et al., 2007; Post et al., 1999). However, this method strongly depends on the colours of the rock fragments and the soil conditions. Indeed, directly following a rain, the presence of the cleaned rock fragments is easier to detect. In contrast, after ploughing, the fine earth embedding the rock fragments can introduce a bias into the estimation of the volume content of rock fragments.

The rock fragment content of the deepest soil layers can be estimated by invasive methods, such as soil sampling. Soil sampling requires digging a pit, and large volumes of soil, i.e., large enough to be representative of the soil particle size distribution, must be sampled in each soil horizon and sieved. A visual estimation can also be performed with a chart, but this method strongly depends on the operator (Folk, 1951; Jeffrey, 1985; Terry and Chillingar, 1955). Thus, a real challenge still exists in terms of estimating the rock fragment content along a soil pit without disturbing the soil.

Geoelectrical methods, such as electrical resistivity profiling, are non-invasive methods that are useful for characterising the spatial variability in soils (Samouëlian et al., 2005; Sudduth et al., 2001). Variations in electrical resistivity result from differences in soil textures, soil structure and some other physical soil properties, including the moisture content and bulk density of the soil (Besson et al., 2004; Seger et al., 2009). However, the electrical resistivity method requires good contact between the soil and electrodes to facilitate the injection of a direct electrical current into the soil. Faulty electrodes can introduce noise into a dataset, i.e., unexpected zero values or very high values. In particular, this noise arises from i) measurement errors due to the measuring device, ii) sporadic errors due to external effects (Tabbagh, 1988) and iii) poor electrode contact that can occur frequently in dry and stony soils.

The presence of rock fragments can strongly affect the electrical signal. Rock fragments located at the soil surface are responsible for noise in the measurement dataset due to interference with electrode/soil contact. In addition, the resistivity of rock fragments is generally higher than the resistivity of fine earth by several orders of magnitude (Schon, 1996; Telford et al., 1976). Several laboratory experimental studies have been conducted to study the electrical properties of rocks (Guichet, 2002; Marescot, 2006; Olhoeft, 1981; 
Version définitive du manuscrit publié dans / Final version of the manuscript published in :

Catena, 92, 67-74

Parkhomenko, 1967; Schon, 1996; Telford et al., 1976). Experimental measurements by Rey et al. (2006) on two-phase heterogeneous media consisting of resistive inclusions embedded in a conductive matrix demonstrated the validity of the model of Bussian (1983) for estimating the volume proportion of rock fragments in the soil. Following these promising experiments, we propose using electrical resistivity data to estimate the volume percentage of rock fragments at the field scale.

The aim of this study was to test the efficiency of the electrical resistivity method for estimating the rock fragment content of soil at the field scale. This analysis was based on two methods. The first method is an application of the model of Bussian (1983) that was previously used by Rey et al. (2006). The second method focuses on noise data extracted from spatial unfiltered electrical resistivities of soil. These geophysical methods were compared to those usually used in the field, visual descriptions from a cartographic survey and measurements of the volume content of rock fragments after soil sampling.

\section{Materials and methods}

\subsection{Study area}

The study area was located in the Beauce region (Villamblain, France) about $110 \mathrm{~km}$ southwest of Paris. It extended over an area of 115 hectares and was generally cropped with maize and wheat (Nicoullaud et al., 2004). The climate was temperate continental with an oceanic influence and was characterised by an average temperature of $10.5^{\circ} \mathrm{C}$, a modal rainfall of about $623-630 \mathrm{~mm}$ and an evapotranspiration of about $767-783 \mathrm{~mm}$ (Besson, 2007; Michot, 2003a; Michot, 2003b). These mean values were calculated over a period of 32 years (1967 to 1996), and the evapotranspiration was calculated using the Penman-Monteith formula. In 1995, i.e., prior to geophysical surveys, 290 auger holes were dug to develop a description of the soils in the study area. The information obtained from the auger holes was used to establish a soil database for the study area. The soils consisted of a loamy-clay layer (about 60\% loam and 30\% clay) developed over lacustrine limestone deposits, which were locally cryoturbed. The thickness of this loamy-clay layer varied between 0.2 and $0.9 \mathrm{~m}$. According to i) the spatial variability of the soil characteristics, ii) the depth and type of limestone where soil horizons were developed and iii) the thickness of the loamy-clay layer, the study area was classified into eight main soil units (Nicoullaud et al., 2004; Besson et al., 2010). These units were mainly haplic calcisols and calcaric cambisols (IUSS Working Group WRB, 2006) containing various quantities of rock fragments with different sizes, from gravels to blocks. As described by King et al. (1999) and Bourennane et al. (1998), the soil units formed on cryoturbed limestone deposits or on soft limestone deposits had the deepest loamyclay layer (up to $0.8 \mathrm{~m}$ deep), whereas the shallowest soils (about $0.3 \mathrm{~m}$ deep) developed directly on hard calcareous bedrock. 


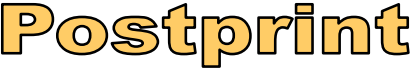

Version définitive du manuscrit publié dans / Final version of the manuscript published in :

Catena, 92, 67-74

In this study area, three plots with surface areas ranging from 1 to 10 ha were worked. The three plots were denoted A, B and C (Fig. 1). These three plots encompassed stony soil horizons with i) various proportions of rock fragments, ranging from $0 \%$ to more than $30 \%$ (volume percentage) and ii) various lithologies, including soft limestone, hard limestone, lithographic limestone and cryoturbed limestone.

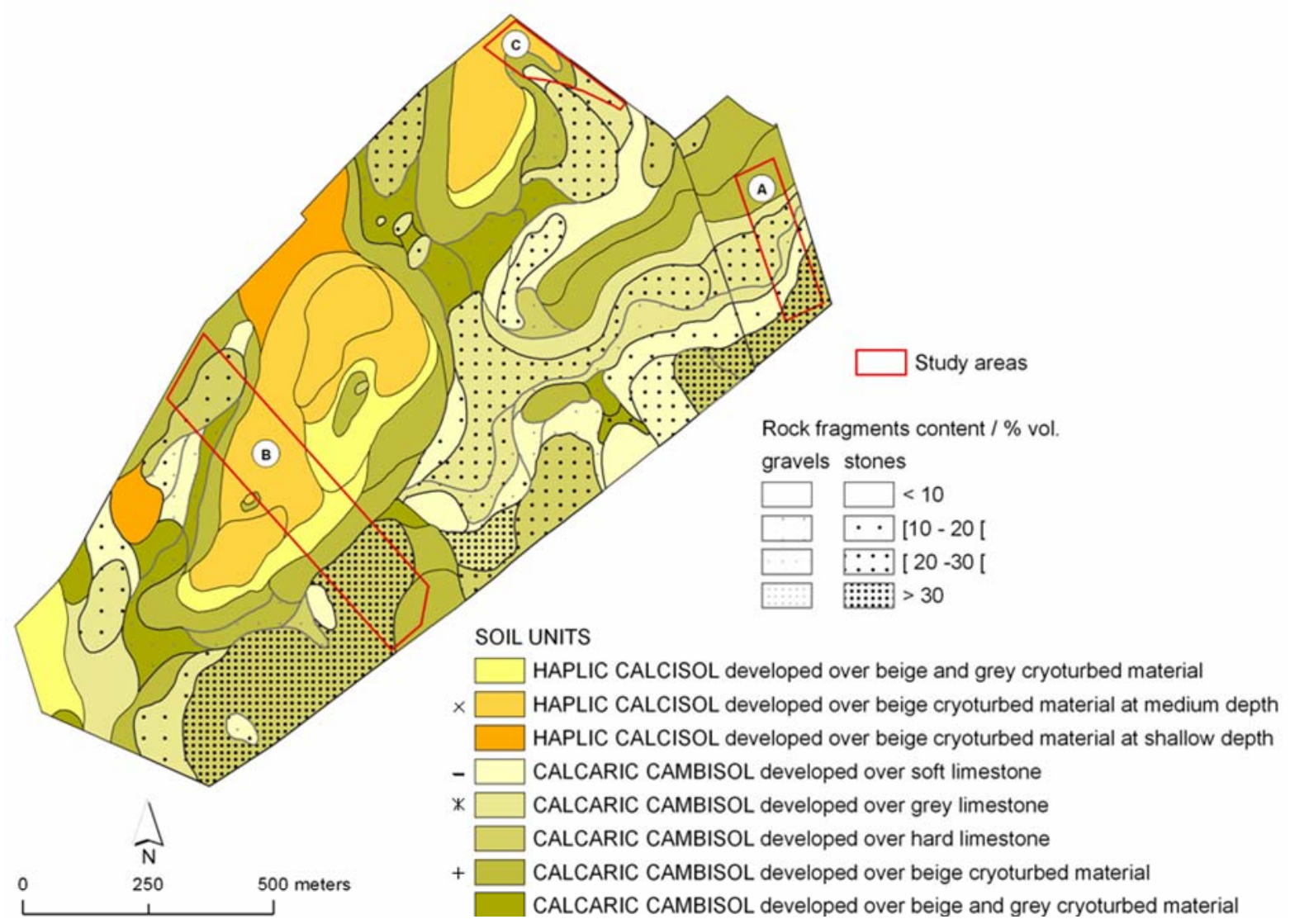

Figure 1: Soil map of the study areas at 1/5000 established in 1995. The soil units were described using the IUSS Working Group WRB (2006) classification. The symbols $(\times,-, *$ and + ) correspond to those used in figure 8 .

\subsection{Electrical resistivity data}

\subsubsection{Electrical resistivity measurements}

Field-scale geophysical surveys were accomplished using a Multi-Continuous Electrical Profiling device (MuCEP device) that allows measurements of spatial field electrical resistivity with a high spatial resolution. The device was composed of a Doppler radar, which triggered a measurement every $0.1 \mathrm{~m}$ along an electrical transect, a global positioning system and four pairs of electrodes that generated three electrical arrays (V1, V2 and V3) coupled with a resistivity meter. Each array was composed of four wheels that acted as metallic probes; two probes ("A" and "B") were used to inject current into the soil, and two other probes ("M" and "N") were used to record the electrical potentials. The spacings between the A-B current probes and the $\mathrm{M}-\mathrm{N}$ potential probes were $0.6 \mathrm{~m}, 1.2 \mathrm{~m}$ and $2.2 \mathrm{~m}$ 


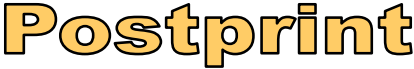

Version définitive du manuscrit publié dans / Final version of the manuscript published in :

Catena, 92, 67-74

for the three arrays. A complete description of this device has been provided by Panissod et al. (1997), Dabas et al. (2001) and Besson et al. (2010).

The spacing between two measurements along a geoelectrical profile was approximately $10 \mathrm{~cm}$, and the spacing between two profiles was $2 \mathrm{~m}$ or $4.8 \mathrm{~m}$ (Table 1). Former studies have shown that the depth of the soil volume investigated was on the order of magnitude of the spacing between the electrodes (Dabas and Tabbagh, 2003). Consequently, the V1 array was mainly used to investigate the loamy-clay layer and a portion of the cryoturbed limestone or soft limestone deposits in some thin areas, whereas the V2 and V3 arrays were used to investigate at greater soil depths. All of the measurements were georeferenced and recorded by a PC.

Table 1: Characteristics of the studied plots.

\begin{tabular}{|c|c|c|c|c|c|c|}
\hline Plot & $\begin{array}{l}\text { Surface } \\
\text { area }\end{array}$ & $\begin{array}{l}\text { Geographical } \\
\text { coordinates }\end{array}$ & $\begin{array}{l}\text { Dates of electrical } \\
\text { resistivity } \\
\text { measurements }\end{array}$ & $\begin{array}{l}\text { Intervals of electrical } \\
\text { resistivity } \\
\text { measurements along } \\
\text { the profiles }\end{array}$ & $\begin{array}{l}\text { Distance } \\
\text { between two } \\
\text { profiles }\end{array}$ & $\begin{array}{l}\text { Determination of rock } \\
\text { fragment content }\end{array}$ \\
\hline A & 2.55 ha & $\begin{array}{l}\text { E1.574 } \\
\text { N47.997 }\end{array}$ & May 2000 & $10 \mathrm{~cm}$ & $4.8 \mathrm{~m}$ & $\begin{array}{l}\text { Visual estimation and } \\
\text { quantitative } \\
\text { measurements after } \\
\text { sampling }\end{array}$ \\
\hline B & 9.60 ha & $\begin{array}{l}\mathrm{E} 1.562^{\circ} \\
\mathrm{N} 47.992^{\circ}\end{array}$ & May 2000 & $14 \mathrm{~cm}$ & $4.8 \mathrm{~m}$ & $\begin{array}{l}\text { Visual estimation and } \\
\text { quantitative } \\
\text { measurements after } \\
\text { sampling }\end{array}$ \\
\hline $\mathrm{C}$ & 1.50 ha & $\begin{array}{l}\mathrm{E} 1.568^{\circ} \\
\mathrm{N} 48.000^{\circ}\end{array}$ & $\begin{array}{l}\text { April } 2006 \\
\text { June } 2006 \\
\text { August } 2006 \\
\text { October } 2006 \\
\text { March } 2007\end{array}$ & $13 \mathrm{~cm}$ & $2.0 \mathrm{~m}$ & Visual estimation \\
\hline
\end{tabular}

Electrical resistivity measurements were conducted on different dates (Table 1) in both wet and dry seasons (May 2000, April 2006, June 2006, August 2006, October 2006 and March 2007). The gravimetric water content present on each date was estimated from bulk soil samples of about $100 \mathrm{~cm}^{3}$ collected in the soil layer at a depth of $0-30 \mathrm{~cm}$.

\subsubsection{D modelling of resistivity based on soil depth}

Electrical resistivity in the loamy-clay layer was estimated using 1D inverse modelling of the apparent measurements (Qwinv1De software; Tabbagh, 2004). The inverse procedure was described by Cousin et al. (2009). The direct calculation corresponded to the analytical computation of the Laplace equation solution for the electrical potential; the final expression was the Hankel transformation, and this computation was performed by convolution. A model with two layers and a fixed thickness parameter was implemented. The first model layer considered the loamy-clay layer, the depth of which was measured by the auger holes. The 
Version définitive du manuscrit publié dans / Final version of the manuscript published in :

Catena, 92, 67-74

second model layer was considered to have an infinite thickness. The resistivities of the two soil layers were defined as variable parameters. Resistivities that were estimated by 1D inverse modelling will be referred to as "interpreted resistivity" in the following sections.

\subsection{Measurements of the volume percentage of rock fragments}

Depending on the subplot, the volume content of the rock fragments was determined using two methods.

\subsubsection{Visual estimation of the rock fragment percentage}

During the 1995 field campaign that aimed to describe the area soil types, the estimation of the rock fragment contents of the three subplots was accomplished using a chart (Folk, 1951; Jeffrey, 1985). At each auger hole location, the rock fragment content was estimated visually in terms of the percentages of surface coverage and of fragment size (gravels, pebbles, stones and blocks). Mean values of the volume content of rock fragments were then calculated for each soil unit.

\subsubsection{Quantitative measurements of the rock fragment proportion}

In plots $\mathrm{A}$ and $\mathrm{B}, 27$ pits were dug down to the bedrock; 18 pits were dug in plot A, and 9 pits were dug in plot B. According to the possibilities of surveys to shovel, within a sampling volume of approximately $500 \mathrm{dm}^{3}$ (length $=1 \mathrm{~m}$; width $=0.5 \mathrm{~m}$; height $=1 \mathrm{~m}$ ) for one pit, samples of soil were then collected in amounts that were large enough to be representative of the sampled soil layers $(60-80 \mathrm{~kg})$. The soil samples were assumed to correspond to Representative Elementary Volumes of rock fragment content.

Rock fragment samples were collected in the loamy-clay layer from the surface to the calcareous bedrock at two levels; the first level was located between 0 and $45 \mathrm{~cm}$, and the second levels was located between 45 and $90 \mathrm{~cm}$ or top of the calcareous bedrock.

The bulk density of each layer was also determined; for non-stony zones, three 500 $\mathrm{cm}^{3}$ soil cylinders were collected, and the excavation method was used for zones with rock fragments (AFNOR, 2009). In the latter case, soil volumes of about $2 \mathrm{dm}^{3}$ were collected.

In the lab, the soil samples were first dried at $30^{\circ} \mathrm{C}$ for 10 days, weighed and then sieved to separate fractions with sizes of $0-2 \mathrm{~mm}, 2-20 \mathrm{~mm}$ and up to $20 \mathrm{~mm}$. Of these fractions, portions of approximately $100 \mathrm{~g}$ were collected and used to determine the dry mass. Following the dry sieving process, the different soil fractions were sieved in water to remove the remaining fine earth coating the rock fragments. The cleaned rock fragments were then dried at $105^{\circ} \mathrm{C}$ for $48 \mathrm{~h}$, and the gravimetric percentage of rock fragments was calculated. 
Version définitive du manuscrit publié dans / Final version of the manuscript published in :

Catena, 92, 67-74

The samples that were collected to estimate the bulk density were dried at $105^{\circ} \mathrm{C}$ for $48 \mathrm{~h}$ and then weighed. The volume proportion of rock fragments collected was then determined for each layer.

\subsection{Modelling of rock fragment content using geoelectrical resistivity values}

\subsubsection{A new model using electrical resistivity noise}

We hypothesised that a relationship exists between the volume content of rock fragments in soil layers and the noise in the electrical resistivity measurements. We then extracted the noise from both the apparent electrical resistivity of the V1 array and the interpreted electrical resistivity.

First, all of the null values were erased. Second, the standard deviation of 160 measurements located within a $5 \mathrm{~m}$ radius around a given point was calculated. Third, the relationships between the standard deviation of the resistivity measurements and the volume proportion of rock fragments in the soil were analysed. However, the electrical signal noise was not due exclusively to the presence of rock fragments; the signal noise also depended on random white noise and equipment noise. Thus, noise exists even for soil with low rock fragment content. Consequently, in our analysis, we did not consider either the soil units with a volume percentage of rock fragments lower than or equal to $15 \%$ or low standard deviation values between 0 and $5 \mathrm{ohm} \cdot \mathrm{m}$.

The relationships between the electrical resistivity measurements and the rock fragment content were first analysed using the dataset of plot A. The relationships were then validated using the dataset of plot $\mathrm{B}$, which was measured on a similar date. A statistical bilateral test was used at the $5 \%$ confidence level for validation.

\subsubsection{The model of Bussian (1983)}

Based on the equation of Hanaï-Bruggeman, Bussian (1983) proposed a model of the effective resistivity for a diphasic medium composed of resistive inclusions embedded in a conductive matrix. We used this model to estimate the volume of rock fragment content $(R F C)$ from the apparent resistivity measurements of the V1 array of Mucep $\left(\rho_{0}\right)$, the electrical resistivity of the fine earth $\left(\rho_{F E}\right)$ and the electrical resistivity of the rock fragments $\left(\rho_{R F}\right)$ :

Erreur ! Signet non défini. $R F C=1-\left(\frac{\left(\frac{\rho_{0}}{\rho_{F E}}\right)^{\frac{-1}{m}}-\left(\frac{\rho_{F E}}{\rho_{R F}}\right)\left(\frac{\rho_{0}}{\rho_{F E}}\right)^{\frac{m-1}{m}}}{1-\left(\frac{\rho_{F E}}{\rho_{R F}}\right)}\right)$

(Eq. 1) 


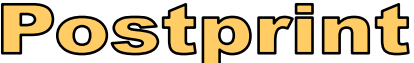

Version définitive du manuscrit publié dans / Final version of the manuscript published in :

Catena, 92, 67-74

Here, $m$ is the cementation factor characterising the tortuosity of the continuous medium.

Apparent resistivity values were first averaged for 160 measurements located within a $5 \mathrm{~m}$ radius around a given point. $\rho_{F E}$ was fixed at $20 \mathrm{ohm} . \mathrm{m}$, corresponding to the mean value of electrical resistivity for non-stony zones in the study area. $\rho_{R F}, m$ and $R F C$ on plot A were then estimated by an optimisation process based on the non-linear least squares method. Consistent with values proposed by Schon (1996), $m$ was set equal to 2.63, and $\rho_{R F}$ was set to $200 \mathrm{ohm} . \mathrm{m}$ for cryoturbed limestone substrate (1000 ohm.m for other calcareous substrates). The parameters defined using the optimisation process were then applied to plot $\mathrm{B}$. The mean absolute error (MAE), the mean error (ME) and the root mean square error (RMSE) were computed to determine the validity of the model.

\section{Results}

\subsection{General description of the dataset}

The volume proportions of rock fragments in plots $\mathrm{A}, \mathrm{B}$ and $\mathrm{C}$ at the soil pit scale are presented in Figure 2. For plots $\mathrm{A}$ and $\mathrm{B}$, the rock fragment contents were measured from soil sampling. For plot $\mathrm{C}$, the rock fragment content was visually estimated. The volume content of rock fragments reached a maximum of $54 \%$ for plot A, 35\% for plot B and $20 \%$ for plot C. Mean values for the rock fragment contents were approximately $20 \%$ for plots A and B and $10 \%$ for plot $\mathrm{C}$. These values exhibited significant dispersion, which suggests that there is a large degree of heterogeneity in the volume content of rock fragments.

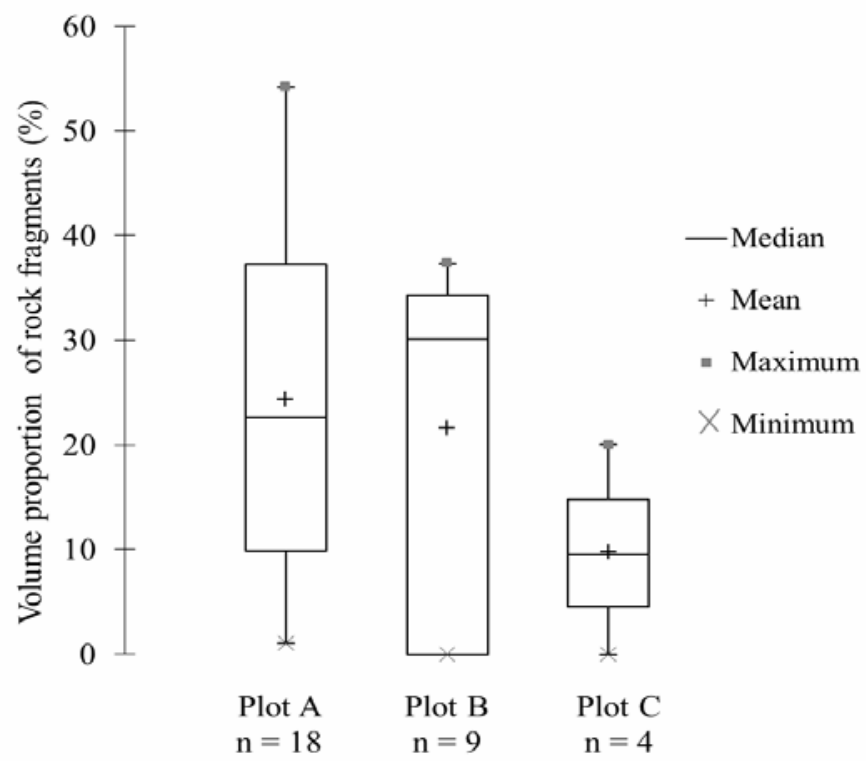

Figure 2: Volume proportion of rock fragments in the three soil plots; $\mathbf{n}$ corresponds to the number of visual observations for plot $C$ and the number of soil pits dug for plots $A$ and $B$. The upper and lower box boundaries indicate the 75 th and the 25 th percentiles, respectively. 


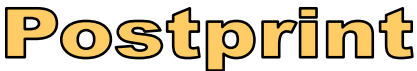

Version définitive du manuscrit publié dans / Final version of the manuscript published in :

Catena, 92, 67-74

Figure $3(a, b, c)$ presents the apparent resistivity maps from the V1, V2 and V3 arrays for plot A. The resistivity values ranged between 5 and 130 ohm.m but showed a spatial organisation based on the soil depth (Fig. 3d). The apparent resistivity increased for thinner soils, i.e., when the bedrock was closer to the surface.

The interpreted resistivity map of the loamy-clay layer allowed the identification of two main areas of electrical resistivity (Fig. 3); the highest values of about 70 to $100 \mathrm{ohm} . \mathrm{m}$ were located in the southeast region of the plot, where the thickness of the loamy-clay layer was relatively small at close to $0.3 \mathrm{~m}$ depth. 


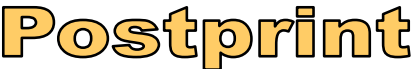

Version définitive du manuscrit publié dans / Final version of the manuscript published in :

Catena, 92, 67-74
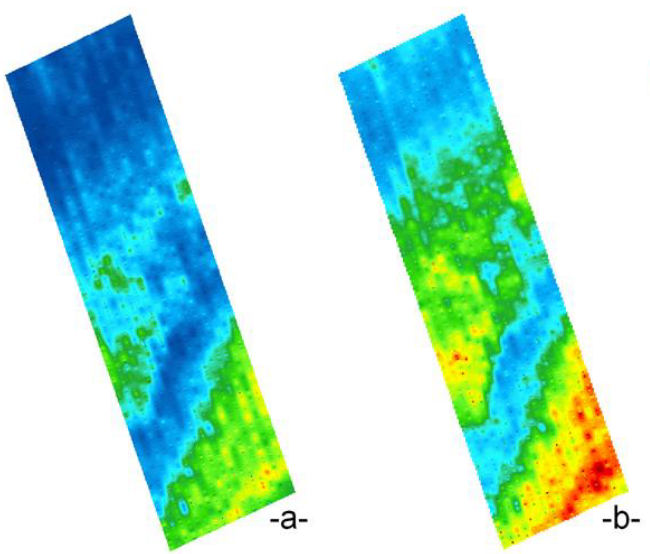

Apparent resistivity / ohm.m

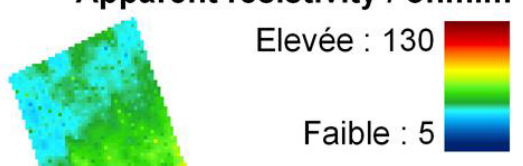

Calculated loamy-clay layer thickness / $\mathrm{m}$
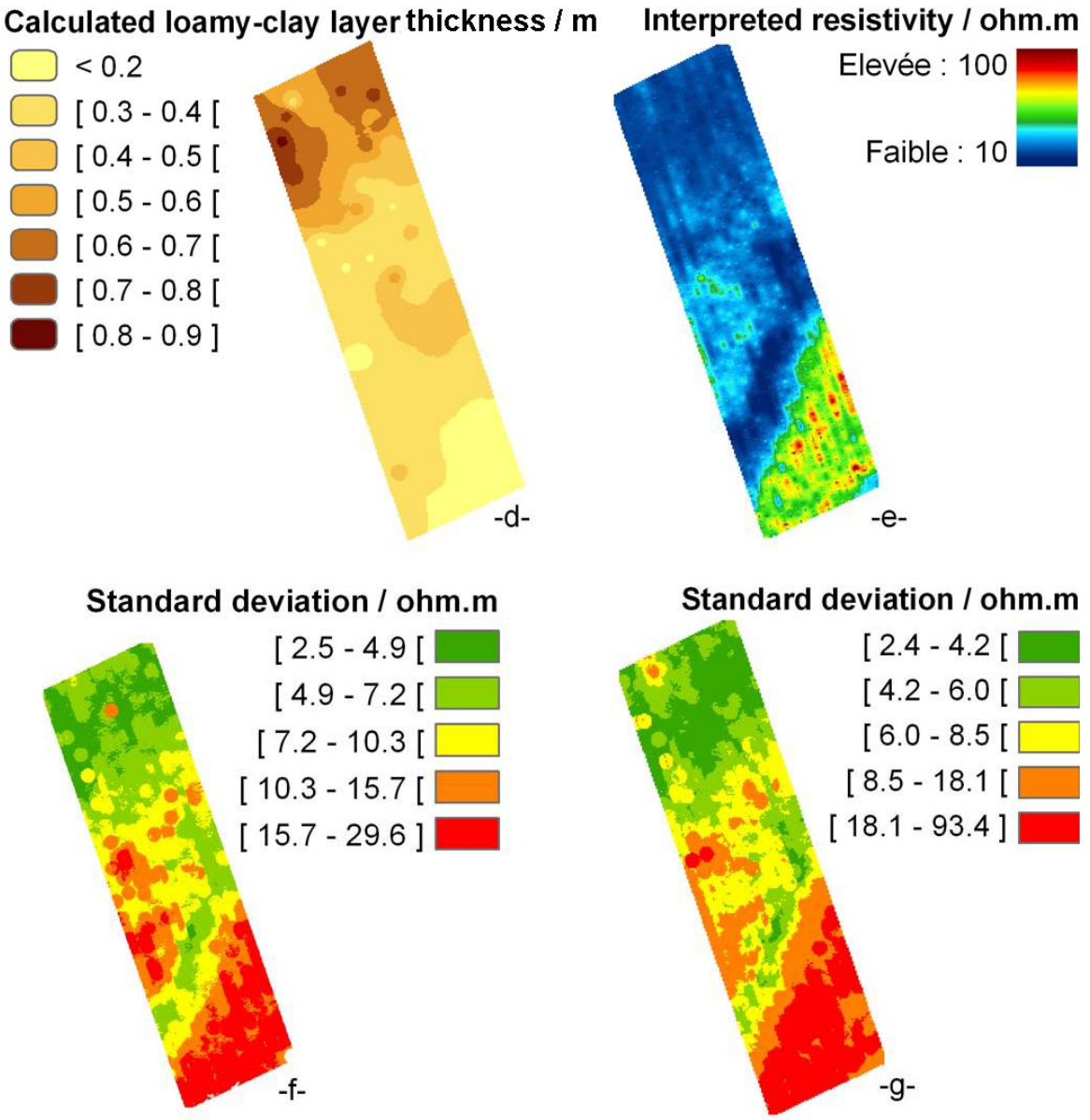

Figure 3: Spatial pattern of data recorded and calculated on plot A. -a-, -b-, -c- : Apparent electrical resistivity measurements for the $\mathrm{V} 1, \mathrm{~V} 2$ and $\mathrm{V} 3$ arrays, respectively. -d- : Map of the loamy-clay layer thickness. -e- : Interpreted electrical resistivity for the loamy-clay layer. -f- : Map of the standard deviations of the electrical resistivity measurements for the V1 array. -g- : Map of the standard deviations of the interpreted electrical resistivity measurements.

\subsection{Estimation of the rock fragment contents at the plot scale}

Comparisons among the apparent resistivity map, the interpreted resistivity map (Fig. 3a and Fig. 3e) and the soil map (Fig. 1) enhanced the localisation of stony soils that exhibit the 


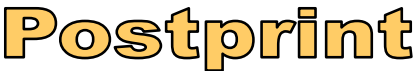

Version définitive du manuscrit publié dans / Final version of the manuscript published in :

Catena, 92, 67-74

highest resistivity values. Standard deviation values for both the apparent and interpreted resistivity maps are shown in Figures $3 \mathrm{f}$ and $3 \mathrm{~g}$. These values ranged from 2 to $90 \mathrm{ohm} . \mathrm{m}$ and exhibited a similar spatial organisation, i.e., the highest values were located in the southeast region where the rock fragment content was the highest.

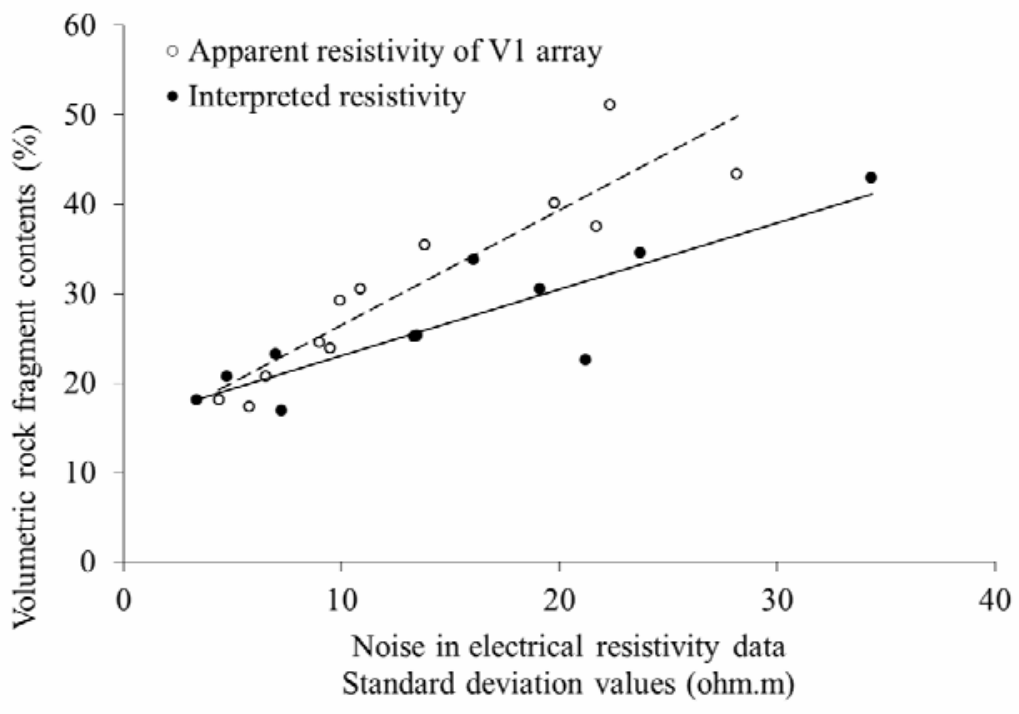

Figure 4: Relationships between the standard deviation of the electrical resistivity data and the measurements of the volume proportion of rock fragments determined on plot $A$.

Linear equations were fitted to the rock fragment content and electrical resistivity data (Fig. 4). For the apparent resistivity data, geoelectrical values were compared to the rock fragment contents at the $0-45 \mathrm{~cm}$ depth. This thickness corresponded to the layer investigated by the V1 array, which can be locally different, i.e., thicker or thinner, than the real loamy-clay layer thickness. For the interpreted resistivity data, geoelectrical values were compared to the rock fragment contents of the entire loamy-clay layer with a variable thickness from 0.2 to $0.9 \mathrm{~m}$.

Table 2: Parameters of the linear equations describing the relationship between rock fragment contents and the electrical resistivity data on Plot $\mathbf{A}$.

\begin{tabular}{|c|c|c|c|c|}
\hline Equation & $\mathrm{n}$ & Slope & Intercept & $\mathrm{R}^{2}$ \\
\hline Volumetric rock fragments $=\mathrm{f}($ mean values of Apparent resistivity $)$ & 18 & 0.79 & -8.44 & 0.77 \\
\hline Volumetric rock fragments $=\mathrm{f}$ (mean values of Interpreted resistivity $)$ & 18 & 0.60 & -0.08 & 0.70 \\
\hline Volumetric rock fragments $=\mathrm{f}($ standard deviation values of Apparent resistivity) & 12 & 1.28 & 13.68 & 0.85 \\
\hline Volumetric rock fragments $=\mathrm{f}($ standard deviation values of Interpreted resistivity) & 11 & 0.74 & 15.67 & 0.77 \\
\hline
\end{tabular}

The results of the statistical regressions are summarised in Table 2. High and significant coefficients of determination ( 0.70 to 0.85$)$ were observed for the four equations. These relationships are in agreement with visual descriptions presented on maps (Fig. 3) in which 


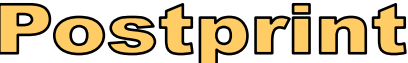

Version définitive du manuscrit publié dans / Final version of the manuscript published in :

Catena, 92, 67-74

the stony areas corresponded to highly resistant zones. However, the highest coefficients of determination ( 0.85 and 0.77$)$ were obtained when the standard deviation values were used instead of the mean values. Thus, these relationships between the rock fragment content and the interpreted or apparent resistivity appeared to be robust equations for calculating the volume percentage of rock fragments at the plot scale; the first equation (i.e. using interpreted resistivity data) provided an estimate of the volume content of rock fragments in the loamyclay layer, whereas the other equation (i.e. using apparent resistivity data) provided an estimate of the volume content of rock fragments in the first layer measured by the V1 array. The latter equation using only the standard deviation of the apparent resistivity is the most robust and easiest relationship; this equation does not require an inversion or knowledge of the soil thickness. In the next section, the standard deviation of the apparent resistivity will be used.

\section{Discussion}

\subsection{Validation using the electrical resistivity noise}

Geophysical surveys were conducted during the same period for plots A and B, and the data from plot B were used for the validation. Six of the nine pits dug on plot B were analysed because the remaining three pits were located in non-stony areas, and the rock fragment content would have been highly overestimated when using geoelectrical data. A significant correlation can be observed between the measured and estimated values for the volume content of rock fragments (Fig. 5) with a root mean square error of $5.4 \%$ (Table 3) even though one point was underestimated by $10 \%$.

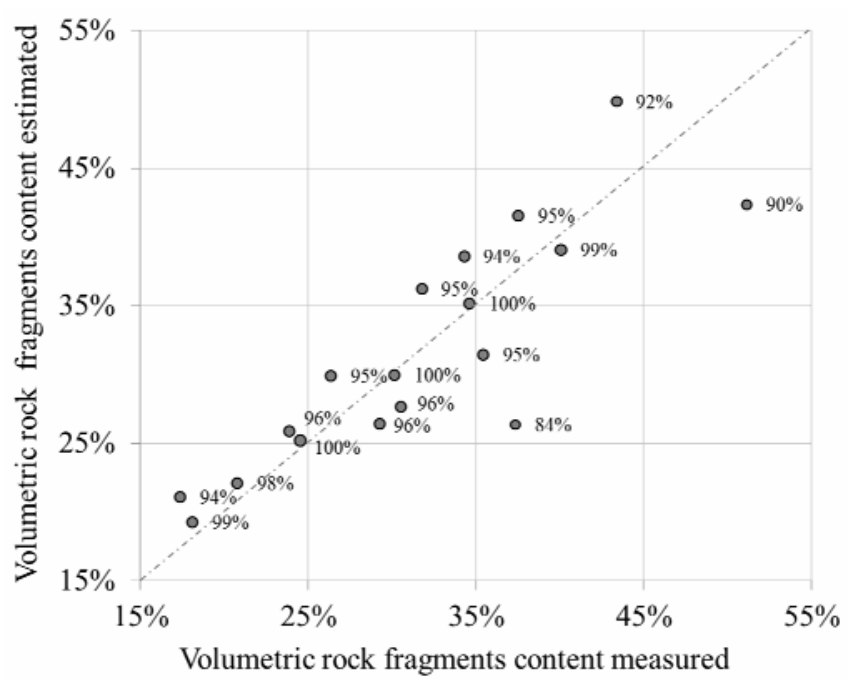

Figure 5: Comparison between the estimated and measured volume proportion of rock fragments. The percentage values represent the risk of rejection of the null hypothesis ("the difference between estimated and measured proportions is equal to 0 ") when it is true. 


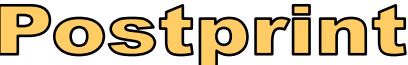

Version définitive du manuscrit publié dans / Final version of the manuscript published in :

Catena, 92, 67-74

Table 3: Mean absolute errors (MAE), mean errors (ME) and root mean square errors (RMSE) for the estimations of the volume rock fragment content using i) the model using electrical resistivity noise and ii) the model of Bussian (1983). $n$ is the number of soil pits used.

\begin{tabular}{lllll}
\cline { 2 - 5 } & Plot A & Plot B & Model using electrical \\
\cline { 2 - 5 } & $\begin{array}{l}\text { Model using electrical } \\
\text { resistivity noise }\end{array}$ & $\begin{array}{l}\text { Model of Bussian } \\
(1983)\end{array}$ & $\begin{array}{l}\text { Model of Bussian } \\
\text { resistivity noise }\end{array}$ \\
\hline $\mathrm{n}$ & 12 & 12 & 6 & 6 \\
MAE & 0.03 & 0.05 & 4.01 & 0.02 \\
ME & $-1.99 \mathrm{E}-06$ & 0.04 & -0.30 & -0.01 \\
$\mathrm{RMSE}$ & 0.04 & 0.06 & 0.05 & 0.03 \\
\hline
\end{tabular}

The map of the measured and estimated rock fragment contents is shown in Figure 6 . The stony areas were correctly located. On plot A, some calculated values were overestimated by about $10 \%$ as compared to the measured values. However, this misestimation is considered to be reasonable and is probably not worse than that of a visual estimation in the field made by a pedologist.
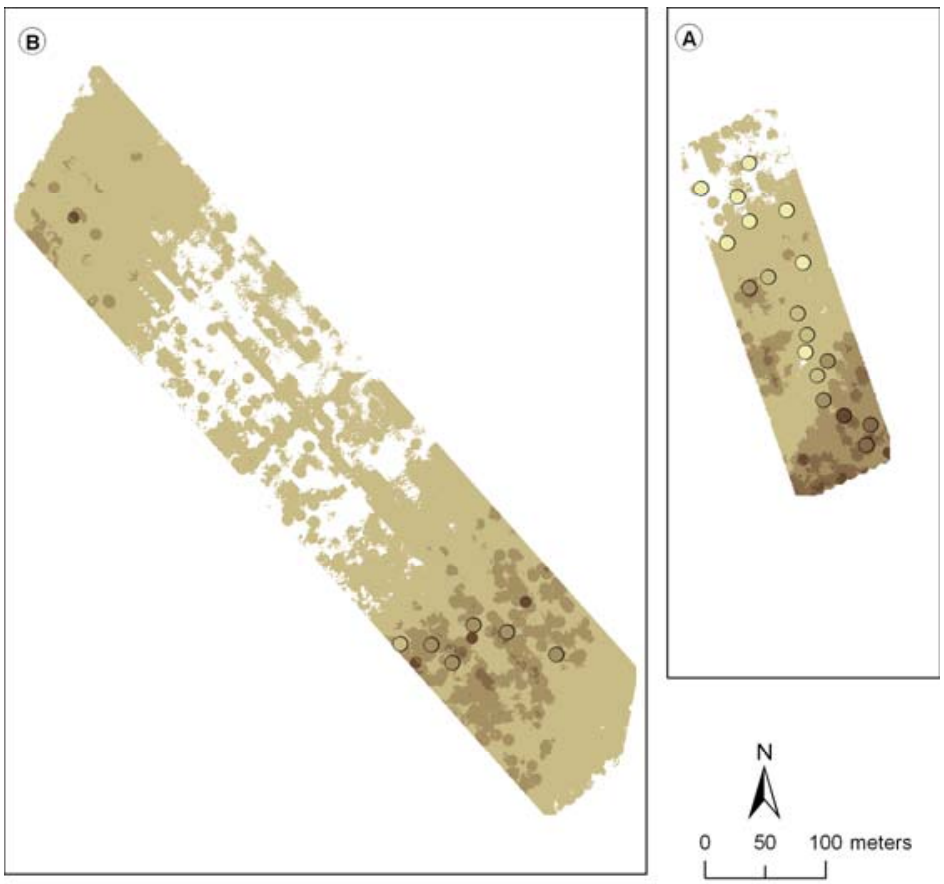

Rock fragments content $/ \%$

Measured

$$
\begin{aligned}
& \text { Estimated } \\
& \begin{array}{|l}
\square<=20 \\
\square \\
\square \\
20-30] \\
30-40] \\
140-50] \\
150-60]
\end{array}
\end{aligned}
$$$$
\begin{aligned}
& <=20 \\
& 120-301
\end{aligned}
$$$$
\text { - } 130-40 \text { ] }
$$$$
140-50]
$$$$
\text { - } 150-601
$$

Figure 6: Maps of the volume proportion of rock fragments for plots $A$ and $B$ as estimated by the noise electrical resistivity method. White areas correspond to no available data.

Thus, our methods appear to be useful for the estimation of rock fragment contents in stony soils. 
Version définitive du manuscrit publié dans / Final version of the manuscript published in :

Catena, 92, 67-74

4.2 Calculation of the rock fragment content using the model of Bussian (1983)

The volume content of rock fragments on plots A and B was calculated by applying Eq. Eq. (1) and compared with the measured values; the estimation of error was less than $6 \%$ (Table 3). The low root mean square error of the estimation shows that the model of Bussian (1983) is well suited for the calculation of the volume content of rock fragments from electrical resistivity data, but a prior calibration of the cementation factor is required.

A comparison of the method using the electrical resistivity noise to the model of Bussian (1983) (Table 3) shows that both models are robust.

\subsection{Effect of water content on the estimation of rock fragment content}

The geophysical surveys of plots A, B and C performed for different water contents in the soil were compared (Fig. 7). The relationship between the standard deviation of the apparent electrical resistivity and the volume content of rock fragments varied with the seasons. In wet seasons, the rock fragment content was less sensitive to the standard deviation values due to their small range. The opposite effect on sensitivity was observed during dry periods.

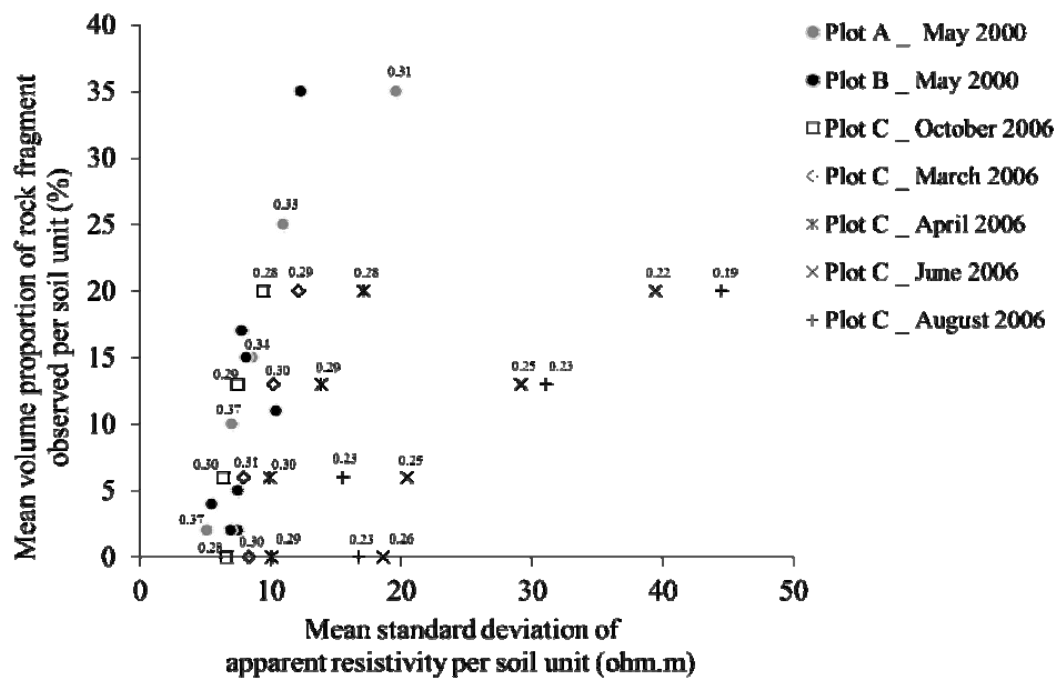

Figure 7: Relationship between the standard deviation of the apparent electrical resistivity data and the volume content of rock fragments. The numerical value above each point represents the mean field water content in $\mathrm{cm}^{3} \mathrm{~cm}^{-3}$. Water content values for plot $A$ and $B$ were similar.

For plot C, five geophysical surveys performed in April 2006, June 2006, August 2006, October 2006 and March 2007 were compared, and the soil at these times contained different water contents. Thus, the effect of the water content of the soil on the relationship between the rock fragment content and the standard deviation of the apparent electrical resistivity could be evaluated (Fig. 8). As expected, the standard deviation of the apparent electrical resistivity was significantly higher when the soil moisture was low. An analysis of variance demonstrated the predominant effect of soil moisture on the standard deviation of the apparent resistivity (Table 4). 
Version définitive du manuscrit publié dans / Final version of the manuscript published in :

Catena, 92, 67-74

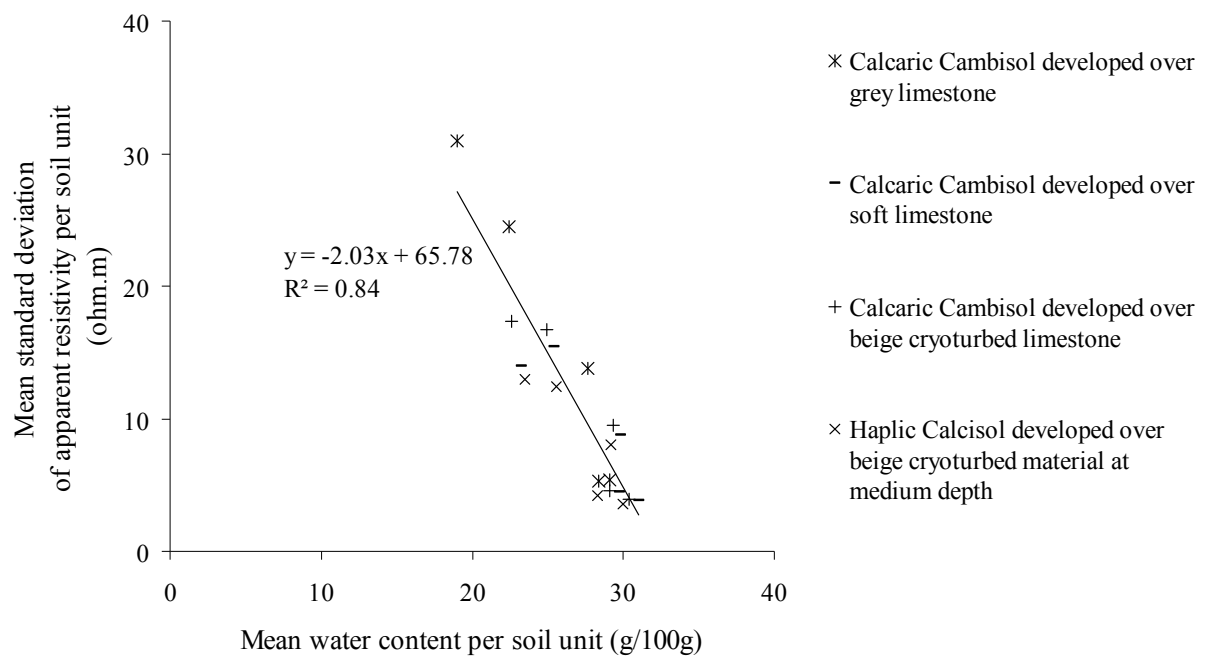

Figure 8: Standard deviation values of the apparent electrical resistivity as a function of water content on plot $\mathrm{C}$. Each symbol refers to soil units previously presented in figure 1.

Table 4: ANOVA for the standard deviations of the apparent resistivity based on both rock fragment and water contents.

\begin{tabular}{llllll}
\hline Sources of variation & Degrees of freedom & Sum of square & Mean Square & F value & $\operatorname{Pr}(>\mathrm{F})$ \\
\hline Rock fragment content & 1 & 144.34 & 144.34 & 15.27 & $0.001^{* *}$ \\
Water content & 1 & 731.90 & 731.90 & 77.42 & $9.75 \mathrm{e}-08^{* * *}$ \\
Residuals & 17 & 160.71 & 9.45 & & \\
\hline
\end{tabular}

To estimate the proportion of rock fragments in the soil, the relationships between the soil volume content of rock fragments and the standard deviations of the apparent resistivities must be calibrated with regard to soil moisture. Moreover, to more accurately determine the rock fragment content of soil, geophysical surveys should be performed during dry periods when the range of the standard deviation of electrical resistivity data is expected to be at its highest.

\section{Concluding remarks}

The method we have developed using electrical resistivity noise allows the qualitative detection of stony areas on zones of a few hectares. Quantitative correlations between the volume percentage of rock fragments and the standard deviation values of electrical resistivity were shown to be as good as those of the model of Bussian (1983) for the estimation of the volume content of rock fragments. Nevertheless, the following recommendation must be considered. 1) To evaluate the signal noise, the unfiltered raw electrical data must be used; filtered data usually produced by commercial devices would allow the prediction of only the locations of stony areas and not the real volume percentage of rock fragments. 2) When the 


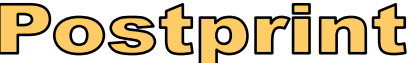

Version définitive du manuscrit publié dans / Final version of the manuscript published in :

Catena, 92, 67-74

proportion of rock fragments is less than $15 \%$, the estimation of the volume content of rock fragments by electrical resistivity becomes more uncertain because noise in the electrical resistivity signal is based on factors besides the presence of rock fragments. As an alternative, the model of Bussian (1983) can be used after a calibration of the cementation factor. 3) To use a relationship between the electrical resistivity data and rock fragment content, calibration data are needed on a plot with equivalent soil types and rock fragment lithologies. 4) The influence of the water content of the soil on the relationship between the electrical resistivity data and the volume content of rock fragments indicates that i) geoelectrical surveys should be performed in dry climate conditions and ii) the relationship with soil moisture should be calibrated.

\section{Appendix: Optimisation process}

On plots $\mathrm{A}$ and $\mathrm{B}$, mean values of electrical resistivity were collected within a $5 \mathrm{~m}$ radius around the given points; these points were focused on the sampling locations for measurements of rock fragment content. The optimisation process was conducted on plot A in two steps. First, $\rho_{F E}$ was fixed at $20 \mathrm{ohm} . \mathrm{m} ; \rho_{R F}, m$ and $R F C$ were estimated by optimisation with the following constraints: i) $0<$ estimated $\mathrm{RFC}<0.55$, ii) $1.3<\mathrm{m}<4$ (Attia, 2005; Pape et al., 1999; Schon, 1996) and iii) $200 \mathrm{ohm} . \mathrm{m}<\rho \mathrm{RF}<1000 \mathrm{ohm} . \mathrm{m}$ (Telford et al., 1976). The optimisation process was then performed to calculate the estimated $R F C$ values by applying Eq. (2.1) within 100 iterations, a tolerance of $5 \%$ and an accuracy of 0.000001 during $100 \mathrm{~s} . m$ and $\rho_{R F}$ values were set to minimise the root mean square error of the estimation of the volume content of rock fragments. $\rho_{R F}$ exhibited a bimodal distribution with two peaks located at approximately 200 and 1000 ohm.m, and $m$ varied between 1.5 and 4 .

In the second step, the $\rho_{R F}$ value was fixed at $200 \mathrm{ohm} . \mathrm{m}$ for a cryoturbed limestone substrate and 1000 ohm.m for the other calcareous substrates. $m$ was set equal to 2.63, corresponding to the median value of the $m$ distribution in the first step. $\rho_{F E}$ was unchanged and set equal to $20 \mathrm{ohm} . \mathrm{m}$. The optimisation process was performed again using these fixed values. Estimates of the $R F C$ values were calculated by applying Eq. (2.1) on plot A and then on plot B.

\section{References}

AFNOR, 2009. Recueil de normes. Qualité des sols - Pédologie. Méthodes physiques. NF ISO 11272: Détermination de la masse volumique apparente sèche.

Attia, A. M., 2005. Effects of petrophysical rock properties on tortuosity factor. Journal of Petroleum Science and Engineering 48, 185-198.

Bhattacharya, J., and Chandrakar, C., 1999. Comparison of three edge detection methods for image analysis of fragmented sandstones and bricks. Fragblast: International Journal for Blasting and Fragmentation 3 (3), 251-265.

Besson, A., Cousin, I., Samouelian, A., Boizard, H., Richard, G., 2004. Structural heterogeneity of the soil tilled layer as characterized by 2D electrical resistivity surveying. Soil \& Tillage Research 79 (2), 239-249.
Besson, A., Cousin, I., Bourennane, H., Nicoullaud, B., Pasquier, C., Richard, G., Dorigny, A., King, D., 2010. The spatial and temporal organization of soil water at the field scale as described by electrical resistivity measurements. European Journal of Soil Science 61 (1), 120-132.

Bouma, J., 1985. Soil variability and soil survey. In Bouma, J., and Nielsen, D.R. (eds). Soil spatial variability. Proc. Soil spatial variability workshop, Las Vegas, NV. 1984. PUDOC Wageningen, The Netherlands. pp 130-149.

Bourennane, H., King, D., Parco, R.L., Isambert, M., Tabbagh, A. 1998. Three dimensional analysis of soils and surface materials by electrical resistivity survey. European Journal of Environmental \& Engineering Geophysics 3, 5-23. 


\section{Version définitive du manuscrit publié dans / Final version of the manuscript published in :}

\section{Catena, 92, 67-74}

Bussian, A.E., 1983. Electrical conductance in a porous medium. Geophysics 48 (9), 1258-1268.

Cousin, I., Nicoullaud, B., Coutadeur, C., 2003. Influence of rock fragments on the water retention and water percolation in a calcareous soil. Catena 53 (2), 97-114.

Cousin, I., Besson, A., Bourennane, H., Pasquier, C., Nicoullaud, B., King, D., Richard, G., 2009. From spatialcontinuous electrical resistivity measurements to the soil hydraulic functioning at the field scale. Comptes Rendus Geoscience 341 (10-11), 859-867.

Dabas, M., Tabbagh, A., Boisgontier, D., 2001. Multi-depth continuous electrical profiling for characterization of in-field variability. 3rd European Conference On Precision Agriculture. Montpellier, France.

Dabas, M. \& Tabbagh, A., 2003. A comparison of EMI and DC methods used in soil mapping-theoretical considerations for precision agriculture. In: Precision Agriculture (eds J. Stafford \& A. Werner), Wageningen Academic Publishers, Muencheberg. pp. $121-129$

Diafas, I., Chiarantini, L., 2011. Evaluation of the DIGISOIL mapping tool with respect to the cost effectiveness. Report $\mathrm{N}^{\circ}$ FP7-DIGISOIL-D4.3. 21 pp.

Folk L., 1951. A comparison chart for visual percentage estimation. Journal of Sedimentary Petrology 21, 32-33

Girard M-C. \& Girard C-M., 1989 - Télédétection appliquée aux zones tempérées et intertropicales, Masson, 260 pp.

Guichet X., 2002. Etude expérimentale des propriétés électriques des roches. Potentiels d'électro filtration, suivi des mouvements de fluides en zones hydrothermales. $211 \mathrm{pp}$.

IUSS Working Group WRB. 2006. World reference base for soil resources 2006

2nd edition. World Soil Resources Reports No. 103. FAO, Rome.

Jeffrey C. R., 1985. Comparison chart for estimating volume percentages of constituents in rocks and concentrates in the range of 1.0 to 0.1 volume percent. American Mineralogist 70, $1318-1319$

King, D., Bourennane, H., Isambert, M., Macaire, J.J., 1999. Relationship of the presence of a non-calcareous clay-loam horizon to DEM attributes in a gently sloping area. Geoderma 89, 95-111.

Mathieu, R., Cervelle, B., Rémy, D., Pouget, M., 2007. Fieldbased and spectral indicators for soil erosion mapping in semiarid mediterranean environments (Coastal Cordillera of central Chile). Earth Surface Processes and Landforms 32, 13-31.

Marescot L., 2006. Introduction à l'imagerie électrique du soussol. Bull. Soc. vaud. Sc. nat. 90.1: 23-40.

Michot, D., Benderitter, Y., Dorigny, A., Nicoullaud, B., King, D., Tabbagh, A., 2003. Spatial and temporal monitoring of soil water content with an irrigated corn crop cover using surface electrical resistivity tomography. Water Resources Research, 39, $1138-1144$

Nicoullaud B., Couturier A., Beaudoin N., Mary B., Coutadeur C. King D., 2004. Modélisation spatiale à l'échelle parcellaire des effets de la variabilité des sols et des pratiques culturales sur la pollution nitrique agricole. In: Organisation spatiale des activités agricoles et processus environnementaux. P. Monestiez, S. Lardon, B. Seguin (eds). Coll. Science Update, INRA Editions, 143-161
Olhoeft, G.R., 1981. Electrical properties of rocks, in Physical Properties of Rocks and Minerals, eds Touloukian, Y.S., Judd, W.R. \& Roy, R.F., McGraw Hill, New York. pp. 257-330.

Panissod, C., Dabas, M., Jolivet, A., Tabbagh, A., 1997. A novel mobile multipole system (MUCEP) for shallow $(0-3 \mathrm{~m})$ geoelectrical investigation: the 'Vol-de-canards' array. Geophysical Prospecting 45 (6), 983-1002.

Pape, H., Clauser, C., Iffland, J., 1999. Permeability prediction based on fractal pore-space geometry. Geophysics 64, 14471460 .

Parkhomenko, E.I., 1967. Electrical Properties of Rocks, eds Plenum, New York. 314 pp.

Post, D.F., Martin, E.S.; Simanton, J.R., Sano, E.E., 1999. Use of hand-held radiometers to evaluate the cover and hydrologic characteristics of semiarid rangelands. Arid Soil Research and Rehabilitation 13 (2), 201-217.

Rey, E., Jongmans, D., Gotteland, P., Garambois, S. 2006. Characterisation of soils with stony inclusions using geoelectrical measurements. Journal of Applied Geophysics 58 (3): 188-201.

Rhoades, J.D., 1993. Electrical conductivity methods for measuring and mapping soil salinity. Advances in Agronomy. 49: 201-251.

Samouëlian, A., Cousin, I., Tabbagh, A., Bruand, A., Richard, G., 2005. Electrical resistivity survey in soil science: a review. Soil \& Tillage Research 83, 173-193.

Schon, J.H., 1996. Physical Properties of Rocks: Fundamentals and Principles of Petrophysics. 600 pp.

Seger, M., Cousin, I., Frison, A., Boizard, H., Richard, G., 2009. Characterisation of the structural heterogeneity of the soil tilled layer by using in situ $2 \mathrm{D}$ and $3 \mathrm{D}$ electrical resistivity measurements. Soil \& Tillage Research 103, 387-398.

Soil Survey Staff, 2010. Keys to Soil Taxonomy. In: U.S.D.A.N.R.C. Service (Editor), Washington, DC. 346 pp.

Sudduth, K.A., Drummond, S.T. \& Kitchen, N.R., 2001. Accuracy issues in electromagnetic induction sensing of soil electrical conductivity for precision agriculture. Computers \& Electronics in Agriculture 31, 239-264.

Tabbagh, A., Dabas, M., Hesse, A., Panissod, C., 2000. Soil resistivity: a non-invasive tool to map soil structure horizonation. Geoderma 97, 393-404

Tabbagh, A., 2004. Qwinv1De software.

Tabbagh, J., 1988. Traitements des données et élimination des valeurs érronées en prospection électrique en continu. Revue d'Archéométrie 12, 1-9.

Telford W.M., Geldart, L.P., Sheriff, R.E., Keys, D.A., 1982. Prospection géophysique. Propriétés électriques des roches, polarisation spontanée, tellurique, magnétotellurique, prospection électromagnétique, eds ERG éditions La Barbannerie, Maurecourt. 221 pp.

Tetegan, M., Nicoullaud, B., Baize, D., Bouthier, A., Cousin, I., 2011. The contribution of rock fragments to the available water content of stony soils: proposition of new pedotransfer functions. Geoderma 165, 40-49. 


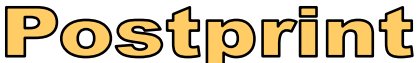

Version définitive du manuscrit publié dans / Final version of the manuscript published in :

Catena, 92, 67-74

Ugolini, F.C., Corti, G., Agnelli, A., Certini, G., 1998. Underand overestimation of soil properties in stony soils. 16th World Congress of Soil Science. Montpellier, France. 